\title{
Privatization one of the 'cures' being considered for NIH
}

\section{Washington}

A US Institute of Medicine panel last week took public testimony on ways in which the intramural programme at the National Institutes of Health (NIH) might be improved.

Nobody denies that NIH are facing difficulties. The most frequently cited problem is money. As federal employees, NIH scientists face salary and benefit limits that do not exist in industry or at academic institutions. But even if salaries could be made more competitive, other issues confront NIH researchers.

It is difficult, for example, to build large research teams at NIH, because personnel numbers are relatively inflexible and laboratory space is at a premium. Travel is also more difficult, as researchers' travel plans must also conform to governmentapproved standards.

Although these problems are not new, headlines last year in the Washington Post saying that National Cancer Institute researcher Robert Gallo was considering leaving NIH focused attention on them. Gallo is widely respected both in the White House and on Capitol Hill for his work on AIDS and the prospect of his departure convinced some that the time had come for action.

One plan considered by the White House Office of Management and Budget would have transferred some of the intramural programme to a private foundation that might run the facility as a research university. Details of the plan were leaked to the New York Times, prompting an outcry that the White House was trying to sell one of the "jewels of the crown", something OMB vigorously denied (see Nature 330 680; 1987). Instead, OMB argued that it was merely looking into ways of preventing any further deterioration of NIH's lustre.

The Institute of Medicine's panel is not. as panel chairman Harold Shapiro, president of Princeton University, took pains to point out, looking solely into the question of privatization.

Shapiro emphasized that the panel would weigh many possible options for improving the intramural programme. One plan, already being considered by Congress, would create a Senior Biomedical Research Service, with "enhanced compensation rates".

But George Cahill, vice-president for scientific training and development at the Howard Hughes Medical Institute, says that salary problems are not limited to senior researchers. Mid-level scientists are also finding it tempting to leave for more lucrative pastures.

Cahill, like others testifying before the panel, agreed that NIH are still an outstanding research centre that will attract top scientific talent. Not only are scientists free from teaching duties at NIH, but they also receive research support directly from their parent institute, an extremely important attraction for researchers anxious to avoid the grant-writing grind.

The institute panel will continue to hear testimony throughout this month, and plans to release its report in October, an extremely short turn-around time. Indeed, some potential witnesses were annoyed at being given only one week's notice of last week's hearing. The panel will accept written comments during the rest of this month.

\section{Drug use a problem at US weapons laboratory?}

\section{Berkeley}

DRug abuse may be widespread at the US government laboratory that conducts research crucial for the next generation of nuclear weapons. According to a congressional report issued last week, an investigation at Lawrence Livermore National Laboratory (LLNL) into illegal drug use by employees, code-named Operation Snowstorm, was apparently more successful than LLNL officials had anticipated. It was called off before the results became too embarrassing, according to the report issued by the House of Representatives energy and commerce subcommittee on oversight and investigations. The report also accuses Department of Energy $(\mathrm{DoE})$ officials of hiding the investigation from subcommittee members.

Operation Snowstorm began in January 1986, when allegations surfaced of drug use by laboratory employees. An undercover officer posing as a truck driver identified 11 possible drug dealers and 24 users inside the laboratory. During the investi-

\section{Livermore clean-up}

\section{Berkeley}

Just one week after a nationwide study criticized US Department of Energy (DoE) laboratories for mismanagement of radioactive waste (see Nature 333, 591; 1988), the DoE's Lawrence Livermore National Laboratory announced plans to build an on-site treatment plant for radioactive and toxic wastes. A laboratory spokesman said the announcement was not a response to the study by the New York-based Radioactive Waste Campaign, but was the culmination of several years of planning for the $\$ 41$ million facility.

The treatment plant, scheduled for completion in 1992, will allow on-site volumereduction and detoxification of 90 per cent of the laboratory's toxic and radioactive waste, compared to current on-site treatment of only 10 per cent.

The laboratory is also beginning a $\$ 60$ million clean-up of a toxic burial site, where leaky drums have contaminated groundwater. gation, he collected information suggesting that more than 100 laboratory employees, including scientists and staff with high security clearances, were using, buying or selling drugs on the job. LLNL officials called off the operation in September 1986, just days before the officer received a security clearance that would have allowed him to investigate the most sensitive areas of the laboratory.

Laboratory officials say the investigation had served its purpose and was called off to begin prosecution of those employees about whom incriminating evidence had been gathered.

Six members of laboratory support staft have been arrested on drug charges, and another 10 were forced to resign. According to a laboratory spokesman, there was insufficient evidence to pursue the remaining 100 or more suspect employees.

But members of the subcommittee as well as the investigators involved in the project accuse DoE and LLNL officials of stifling the investigation, when it had only begun to scratch the surface.

One investigator, Tim Mitchell, told a congressional hearing last week that he was warned not to investigate a laboratory chemist with high security clearance, Ronald K. Stump. Mitchell also said that $\$ 11,000$ worth of precious metals had been checked out from the laboratory in his name, and not recovered.

During subcommittee hearings last week on the drug charges, several laboratory investigators who took part in Operation Snowstorm quoted John Hunt, head of security at LLNL, as saying that if the investigation were to continue, "we would have to arrest 20 per cent of the lab". But Hunt denies having made the comment, according to a laboratory spokesman. When Operation Snowstorm was prematurely cancelled, the investigators complained, and each has subsequently been demoted.

Not convinced that the problem has yet been cleared up, the subcommittee has asked LLNL director John Nuckolls to submit a written proposal outlining further action he plans to take.

Marcia Barinaga 